\title{
Foundational Sources and Purposes of Authority in Australian Law
}

\author{
Danial Kelly \\ School of law, Charles Darwin University \\ Danial.Kelly@cdu.edu.au
}

\begin{abstract}
This article sets out a fundamental approach to understanding the nature of authority in the Australian legal system. The article positions the Australian legal system within its English and Western heritage with an emphasis on the most significant and relevant doctrines of jurisprudence. The tension between the courts and the parliament is set out with attention being directed to the most fundamental source of authority, namely the demos.
\end{abstract}

Keywords: Foundational Sources, Purposes, Authority, Australian Law

\section{A. Introduction}

The starting point in understanding Australia's socio-legal place in an international context is to be familiar with its Western legal tradition. ${ }^{1}$ Some of the characteristics of the Western idea of law include the separation of law from other normative systems (such as religion), the centrality or primacy of law as a method of regulating society, and the inherent authority of law. ${ }^{2}$ Other major socio-legal features

1 Patrick Parkinson, Tradition and Change in Australian Law, 4th ed, Lawbook Co, 2010, p. 23.

2 Ibid, p. 23-28. 
of contemporary Australia include a multicultural population ${ }^{3}$ and government by representative democracy. ${ }^{4}$ Australian law has sprung out of the English branch of the Western legal tradition, ${ }^{5}$ therefore the English heritage of Australian law will first be considered.

Beginning students of Australian law are often confused about the source and nature of fundamental authority in the Australian legal system. Whilst they are usually easily able to cite cases and legislation, new students of Australian law typically tend to struggle with locating the fundamental source and nature of law.

\section{B. The English Heritage of Australian law}

The location and division of authority in English law has changed over time. ${ }^{6}$ Prior to the thirteenth century the English Monarch enjoyed supreme authority in England and shared little of that authority other than with the Christian Church.7 The Magna Carta of 1215 recorded inter alia a decisive limiting of the authority of the King, an increase in power to the barons who would become the predecessors of Parliament, and the embryonic stage of what would later be described as 'rule of law'. ${ }^{8}$ Rule of law becomes a re-occurring theme in English legal history and will be discussed further later in this chapter.

The theory of the divine right of kings (that 'God had not only called the monarch to the throne, but had given him a sacred charac-

3 Around one quarter of the Australian population of 2009 was born overseas: Australian Bureau of Statistics, History of overseas-born in Australia (11 August 2012) Australian Bureau of Statistics < http:/ / www.abs.gov.au/ ausstats/abs@.nsf/Products / 4BBDEB57F94B0682CA25776E00178931?op endocument $>$.

4 s 24, Australian Constitution.

5 Robert Hughes and Geoffrey Leane, Australian Legal Institutions: Principles, Structure and Organisation, JL Law, 1997, p. 36.

6 Henry Hallam, Hallam's Constitutional History of England, Ward, Lock \& Co, circa, 1850 , p. 18.

7 See for example 'William I: Ordinance on Church Courts' reproduced in Carl Stephenson and Frederick George Marcham, Sources of English Constitutional History, Harper \& Row, 1937, p. 35.

8 Magna Carta of 1215. The English concept of 'rule of law' as expounded by Dicey occurs in the proceeding discussion. 
ter and ordained that he should enjoy unrestricted power' $)^{9}$ was expounded by King James I in the sixteenth century. ${ }^{10}$ The divine right of kings doctrine has enjoyed wide acceptance at times, at least for its practical absolutist applications if not so much for its theocratic claims. ${ }^{11}$

In the tumultuous reign of King Charles I (1625 - 1649) the Parliament and the Monarch were engaged in drastic measures to determine power sharing arrangements, not only between the Parliament and the Monarch but also between them both and the judiciary. Reflective of this power struggle is the Act Abolishing Arbitrary Courts which the Parliament passed in 1641 and which reads:

declared and enacted by authority of this present parliament, that neither his majesty nor his privy council have or ought to have any jurisdiction, power, or authority by English bill, petition, articles, libel, or any other arbitrary way whatsoever, to examine or draw into question, determine, or dispose of the lands, tenements, hereditaments, goods, or chattels of any the subjects of this Kingdom, but that the same ought to be tried and determined in the ordinary courts of justice and by the ordinary course of the law ${ }^{12}$

Judicial independence from the legislature was enhanced in the Act of Settlement 1701 by requiring both houses of parliament to be involved in removing judicial officers from their office ${ }^{13}$ as opposed to the whim of a monarch or a prime minister. This aspect of judicial independence finds modern expression in the Supreme Court Act 1981 (UK). ${ }^{14}$ In modern times the Westminster Parliament, especially the House of Commons, enjoys almost prerogative legislative power, ${ }^{15}$ although Parliament still seeks assent of the Monarch for its legislation to have the force of law. ${ }^{16}$

In his seminal work Introduction to the Study of the Law of the

9 W J V Windeyer, Lectures on Legal History, 2nd ed, Law Book Co, 1957, p. 196.

10 Ibid

11 Ibid

12 Act Abolishing Arbitrary Courts 1641, 16 Charles I, c 10.

13 Act of Settlement 1701, 12 and 13 William III, c 2.

14 Section 11(3).

15 Parliament Act 1911, 1 and 2 Geo 5, c 13.

16 Ibid ss 2, 4. 
Constitution ${ }^{17}$ the eminent English jurist, A V Dicey, recorded 'two or three guiding principles which pervade the modern constitution of England'. ${ }^{18}$ According to Dicey ' $[\mathrm{t}]$ wo features have at all times since the Norman Conquest characterised the political institutions of England. ${ }^{\prime 19}$

The first of these features is the omnipotence or undisputed supremacy throughout the whole country of the central government. This authority of the state or the nation was during the earlier periods of our history represented by the power of the Crown. The King was the source of law and the maintainer of order...This royal supremacy has now passed into that sovereignty of Parliament. ${ }^{20}$

Whilst Dicey observes that Parliament has received the undisputed supremacy of authority that previously resided in the Crown, he writes that part of modern English constitutionalism is the doctrine of separation of powers between the three arms of government: the legislature, the executive and the judiciary. Dicey distinguishes the English application of this doctrine from the French jurisprudence as expounded by Montesquieu ${ }^{21}$ and points to the English experience of the reverence that surrounds the independent judiciary as a defining difference between the two. ${ }^{22}$ However, there is no doubt in Dicey's mind that these three arms of government have only one source of authority, namely the Parliament. Dicey declares that the 'executive of England is in fact placed in the hands of a committee called the Cabinet' ${ }^{23}$ who are members of the Parliament. Case law, that is law made by the authority of the Courts, is termed by Dicey as 'judicial legislation" ${ }^{24}$ which, he asserts 'is, in short, subordinate legislation, carried on with the assent and subject to the supervision

17 A V Dicey, Introduction to the Study of the Law of the Constitution, 5th ed, Macmillan, 1897.

18 Ibid, preface v.

19 Ibid, p. 175.

20 Ibid

21 Esprit des Lois, Book XI. c. 6, cited in Dicey, above n 158, 314.

22 Dicey, above n 158, 327.

23 Ibid, p. 8.

24 Ibid, p. 58. 
of Parliament. ${ }^{25}$

Dicey continues with the second feature that characterises English constitutionalism, namely 'the rule or supremacy of law [which] is closely connected with' the supremacy of authority of Parliament. ${ }^{26}$ Dicey defines the phrase 'rule of law' in the English context to consist of three distinct but related aspects, namely:

1. 'no man is punishable or can be lawfully made to suffer in body or goods except for a distinct breach of law established in the ordinary legal manner before the ordinary Courts of the land, ${ }^{27}$

2. 'every man, whatever be his rank or condition, is subject to the jurisdiction of the ordinary tribunals, ${ }^{, 28}$ and

3. 'the constitution is pervaded by the rule of law... [as] the result of judicial decisions determining the rights of private persons. ${ }^{29}$

Dicey's conceptualisation of supremacy of Parliament and rule of law have gained wide acceptance among common law jurists and many subsequent jurists have embraced and further developed Dicey's ideas. ${ }^{30}$

Morison identifies in the writings of some of the classic English legal scholars such as Dicey and Pollock a 'belief in the validity of continuing values, enshrined in the law... [and] anxiety about threats to those values from social factors developing outside the law. ${ }^{31}$ Morison contends that this is the very reason why Pollock attempted 'to pin down such of the law as could be pinned down through codifying various branches of it. ${ }^{32}$ Other appeals have been made to associate law with common sense as a means of attributing authority to it, even

25 Ibid.

$26 \mathrm{Ibid}, \mathrm{p} .175$.

$27 \mathrm{Ibid}, \mathrm{p} .179$.

28 Ibid, p. 185.

29 Ibid, p. 187.

30 R M Unger, 'Law in Modern Society' (1976) reproduced in M D A Freeman, Lloyd's Introduction to Jurisprudence, 7th ed, Thomson, 2001, p. 735.

31 W L Morison, 'Frames of reference for legal ideals' in Eugene Kamenka, Robert Brown, and Alice Erh-Soon Tay (eds) Law and Society: The Crisis of Legal Ideals, Edward Arnold, 1978, p. 18.

32 Ibid. 
proposing that the law itself is a monument to common sense. ${ }^{33}$

Whilst the concept of utilitarianism as formulated by Jeremy Bentham and refined by John Austin attempts to promulgate its own inherent authority in the notion of the greatest happiness of the greatest number, it still relies upon the 'command of the sovereign' to lend authority to law. ${ }^{34}$ The American Roscoe Pound's 'conception of law as a handmaiden to the general forces of social development ${ }^{35}$ allows furtherance of the utilitarian enterprise without the explicit need for sovereign command upon which Bentham and Austin rely. By Pound's conceptualisation, received ideals, whether from a sovereign, religion, custom or another source, become merely one of a number of possible sources of authority together with whatever else is found in contemporary society. Pound hypothesised successive states of development in law in accordance with the level of development of the society in which it functions, namely 'primitive law, strict law, equity and natural law, maturity of law' and a further stage of law that attempts to 'satisfy as much as possible of the sum total of human demand' ${ }^{36}$

Pound's pragmatic formulation of law as a handmaiden to the general forces of social development carries the risk of forgetting that 'reasoning can justify itself only in terms of some source of norms' ${ }^{37}$ When norms are plural and incompatible 'the greatest happiness' becomes even more relative than when a single norm exists, such as the Sovereign. When society is used as a 'reference for formulating ideals for law... rather than finding ideals in law', ${ }^{38}$ as in Pound's pragmatic approach, Hume's warning of the futility of attempting to derive 'ought' from 'is' ${ }^{39}$ is ignored.

33 Ibid, p. 20.

34 Ibid.

35 Ibid, p. 24.

36 Ibid, p. 23, citing Roscoe Pound, I Jurisprudence (St Paul, 1959), p. 366 and 432.

37 Ibid, p. 33.

38 Ibid, p. 31.

39 Hume, 'A Treatise of Human Nature' in M D A Freeman, Lloyd's Introduction to Jurisprudence 7th ed, Thomson, 2001, p. 28. 


\section{The Commonwealth of Australia}

Beginning in the late eighteenth century efforts were made by the English to establish colonies on the continent of Australia. ${ }^{40}$ The Commonwealth of Australia was founded as a nation in 1901 by the federation of the colonies that had developed on the continent into member states of the new nation. ${ }^{41}$ By counting the Australian states, territories and the Commonwealth, there are nine major judicial systems in Australia, yet there is only one common law, achieved through the application of the doctrine of precedent and the apex of the High Court of Australia for all Australian courts. ${ }^{42}$ The legal purposes of the Commonwealth Parliament are restricted to the specific powers given to it by the Constitution, predominantly those in $\mathrm{s} 51$. Thus there are two primary sources in Australian law other than the Constitution, namely legislation and case law. ${ }^{43}$

In terms of sources of authority, the Commonwealth of Australia derives its authority from the Westminster Parliament, specifically 'the Queen's most Excellent Majesty, by and with the advice and consent of the Lords Spiritual and Temporal, and Commons... and by the authority of the same. ${ }^{34}$

Authority in the Commonwealth of Australia is separated into three arms of government: the parliament, the executive and the judiciary. ${ }^{45}$ The constitutional document of the Commonwealth of Australia asserts that legislative authority for its jurisdiction rests in

40 George B Barton, History of New South Wales from the Records, Volume 1: Governor Phillip, 1783-1789, Charles Potter Government Printer, 1889, p. 481.

41 Commonwealth of Australia Constitution Act 1900 (Imp) 63 \& 64 Vict.

42 Australian Constitution s 73; Lipoharv The Queen (1999) 200 CLR 485, 505-6.

43 Hughes and Leane, above n 146, 44.

44 Preamble, Commonwealth of Australia Constitution Act 1900 (Imp) 63 \& 64 Vict.

45 For the Commonwealth of Australia see the Australian Constitution Chapter I, II and III. For the Northern Territory of Australia see Northern Territory (Self-Government) Act 1978 (Cth) Part III and IV in respect to legislative and executive power; for judicial power see Supreme Court Ordinance 1911 (Cth) No. 9 of 1911, Northern Territory Supreme Court Act 1961(Cth) and Supreme Court Act 1979 (NT). 
the Commonwealth Parliament. ${ }^{46}$ Similarly, the Australian Constitution asserts that executive authority is 'vested in the Queen and is exercisable by the Governor-General as the Queen's representative' who in turn is advised by a Federal Executive Council constituted by members of the Commonwealth Parliament. ${ }^{47}$ Judicial authority in the Commonwealth is asserted by the Constitution to be vested in the High Court of Australia. ${ }^{48}$ The Australian Constitution can be changed by referendum. ${ }^{49}$ Within its jurisdictional borders Australian law asserts sovereignty: it asserts itself upon all persons within its jurisdictional borders and it asserts its own supremacy should a conflict of laws arise. ${ }^{50}$ Barring a few odd exceptions, ${ }^{51}$ this monopoly over legal authority permeates the Commonwealth system.

The Australian legal system has been described as a 'product of a tradition of so-called 'liberal' thinking about law, politics, economics and social relations' which 'involves beliefs about the sanctity, the uniqueness and the priority of the individual human being..$^{52}$ Liberal ideology has 'eschewed any direct relationship between religion and politics or law. It has adopted the view that legal knowledge is a matter of technique concerned with the manipulation of technical rules'. ${ }^{53}$

\section{Human Rights}

International human rights morality, expressed in international hu-

46 For the Commonwealth of Australia see Commonwealth of Australia Constitution Act 1900 (Imp) 63 \& 64 Vict, c 12, covering clause 5 and Australian Constitution ss $51-53$. For the Northern Territory of Australia see Northern Territory (Self-Government) Act 1978 (Cth) s 6.

47 Australian Constitution ss $61-64$.

48 Australian Constitution ss 71, $73 \& 75$.

49 Australian Constitution s 128.

50 Australian Constitution cl 5.

51 Such as native title (see Native Title Act 1993 (Cth) s 223) and the rules of statutory interpretation when interpreting domestic legislation enacted pursuant to an international instrument (see Koowarta $v$ Bjelke-Peterson (1982) 153 CLR 168, 265; Acts Interpretation Act 1901 (Cth) s 15AB(2)(d).)

52 Hughes and Leane, above n 146, 2.

53 Ibid, p. 5. 
man rights law, is often touted as having great influence upon modern Australian law. For example, Brennan J in Mabov Queensland (No 2) opined that 'it is imperative in today's world' for the common law to 'keep in step with international law'. ${ }^{54}$ There exists a common law presumption that legislation is made in accordance with human rights. ${ }^{55}$ However, the parliament has prerogative to enact legislation that will not be bound by the enactments of previous governments nor defeated by the common law. An Australian parliament enjoys supremacy in law making for the life of the parliament subject to Constitutional constraints. Therefore, while international human rights law has influenced Australian law it cannot be said that human rights law forms an essential element of the character of Australian law.

\section{E. The Demos and Legislation}

As the parliaments - the bodies empowered to enact legislation - are constituted by democratically elected representatives of the demos, it is this demos that is the primary source of authority in the Australian legal system. Certainly the Constitution describes the mechanisms by which legal authority is established, but in summary and in effect the mechanisms that the Constitution provide are for the contemporary demos to determine the contemporary legislative program, within the parameters of possibility set out in the Constitution for the Federal government (but wider, indeed plenary, possibilities for the States). This approach to jurisprudence does not deny or belittle valid debates on interpreting the Constitution, that is, whether the meaning of the words of the Constitution should be what they were when the Constitution was formed or what they may mean contemporarily, if there is a difference. ${ }^{56}$ Rather, the debates over interpreta-

54 Mabo v Queensland (No 2) (1992) 175 CLR 1, 41-42 (Brennan J).

55 Al-Kateb v Godwin (2004) 219 CLR 562, p. 130.

56 See for example: Jeffrey Goldsworthy, 'Interpreting the Constitution in Its Second Century' (2000) 24(3) Melbourne University Law Review 677. Obiter in the recent decision of Commonwealth $v$ Australian Capital Territory [2013] HCA 55 forcefully opposes original interpretation theory in respect to interpreting the Constitution: [16-19]. 
tion are seen in the larger perspective of the whole system of government which allows for Courts to interpret legislation but also allows for parliaments to enact legislation in response to an unfavourable Court interpretation. Thus while separation of powers exists, the legislature remains able to respond to a decision of a Court, even to enact retrospective legislation. ${ }^{57}$ (This does not apply to High Court interpretations of the Constitution, though even then a referendum is possible.)

The contemporary demos are the contemporary members of the population who are able to vote. ${ }^{58}$ Members of parliament are elected via periodical elections..$^{59}$ The jurisdiction is divided into geographical 'seats', each seat electing one representative to parliament by the majority vote. ${ }^{60}$ This system enables the demos to rule not directly and immediately, but indirectly via their representatives and at intervals by the holding of an election. Nevertheless, the authority for legislation is still sourced from the demos via the parliamentarians.

As the contemporary demos provide the source of authority for legislation, the content of legislation can change radically from one contemporary group to another. These changes in legislative content are not limited to any set morality, that is the morality of one contemporary demos may also be radically different to the morality of another.

\section{F. Conclusions}

Australian law has an English heritage. Whereas originally all legal authority in English law was sourced from the monarch, that authority has been, over time, divested to the parliament, the executive and the judiciary. An evolution of the doctrines of supremacy of parlia-

57 R v Kidman (1915) 20 CLR 425; Rodwayv The Queen (1990) 169 CLR 515.

58 Australian Constitution, s 24.

59 Australian Constitution, ss 13, 28.

60 The methods of determining the winners of seats differ from parliament to parliament but generally speaking all of the methods embrace a majority approach. 
ment, separation of powers and rule of law has occurred in English government and has been transmitted to the Australian system. The constitutional documents of the Commonwealth of Australia assert their authority in legislative, executive and judicial matters and do not allow for alternative sources of authority (other than the source of their derived authority).

As the general purpose of the Commonwealth system is to make laws to regulate behaviour, they are appropriately described as normative systems. The purpose of the Commonwealth Parliament is restricted to certain prescribed areas of law making. Parliament is 'the institution that gives consent to government ... the government of the realm is the business of the Crown and its immediate servants'. In the Australian context, parliament derives its legal authority from constitutional powers and social authority from the demos who elect the parliamentarians (according to constitutional provisions). The ultimate source of authority is the demos as they also have the power to change the Constitution.

\section{Bibliography}

Australian Bureau of Statistics, History of overseas-born in Australia (11 August 2012) Australian Bureau of Statistics <http:/ / www.abs. gov.au/ausstats/abs@.nsf/Products/4BBDEB57F94B0682CA2 5776E00178931?opendocument>.

Barton, George B., 1889, History of New South Wales from the Records, Volume 1: Governor Phillip, 1783-1789, Charles Potter Government Printer.

Dicey, A V., 1897, Introduction to the Study of the Law of the Constitution, $5^{\text {th }}$ ed, Macmillan.

Freeman, M D A,2001, Lloyd's Introduction to Jurisprudence $7^{\text {th }}$ ed, Thomson.

Henry Hallam, 1850, Hallam's Constitutional History of England, Ward, Lock \& Co, circa.

Hughes, Robert and Geoffrey Leane, 1997, Australian Legal Institutions: Principles, Structure and Organisation, JL Law, 1997. 
Goldsworthy, Jeffrey, 2000, 'Interpreting the Constitution in Its Second Century’24(3) Melbourne University Law Review 677.

Kamenka, Eugene, Robert Brown, and Alice Erh-Soon Tay (eds), 1978, Law and Society: The Crisis of Legal Ideals, Edward Arnold.

Parkinson, Patrick, 2010, Tradition and Change in Australian Law, $4^{\text {th }}$ ed, Lawbook Co.

Stephenson, Carl and Frederick George Marcham, 1937, Sources of English Constitutional History, Harper \& Row.

Unger, R M, 1976, “Law in Modern Society” reproduced in M D A Freeman, Lloyd's Introduction to Jurisprudence, $7^{\text {th }} \mathrm{ed}$, Thomson, 2001, p. 735.

Windeyer, W J V., 1957, Lectures on Legal History, $2^{\text {nd }}$ ed, Law Book Co.

\section{Laws, legislations, and Court cases}

Acts Interpretation Act 1901

Act Abolishing Arbitrary Courts 1641.

Act of Settlement 1701.

Al-Kateb v Godwin (2004).

Australian Constitution.

Commonwealth of Australia Constitution Act 1900.

Koowarta $v$ Bjelke-Peterson (1982).

Native Title Act 1993.

Northern Territory Supreme Court Act 1961.

Northern Territory (Self-Government) Act 1978

Mabo v Queensland (No 2) (1992).

Magna Carta of 1215.

Parliament Act 1911.

$R v$ Kidman (1915)

Rodwayv The Queen (1990).

Supreme Court Act 1979 (NT).

Supreme Court Ordinance 1911. 